\title{
SUBSTRATE-FREE EPIDIDYMAL-LIKE BOVINE SPERMATOZOA
}

\author{
G. W. SALISBURY AND G. N. GRAVES \\ Department of Dairy Science, University of Illinois, Urbana, Illinois, U.S.A.
}

(Received 23rd April 1963)

\begin{abstract}
Summary. A technique is presented for the collection of ejaculated bovine spermatozoa directly into an inhibitory diluent which renders the cells immotile and prevents the absorption of carbohydrate from the seminal plasma. When removed from the inhibitory diluent, such cells have low endogenous respiration which is markedly increased by the addition of fructose to the incubation medium or by pre-incubation in a fructose solution before washing and then subjecting the cells to a period of endogenous respiration. After storage at $5^{\circ} \mathrm{C}$ for $24 \mathrm{hr}$ in the collection medium, and after their subsequent removal from the inhibitory medium, the endogenous respiration rate of such spermatozoa and their respiration in the presence of fructose is greater than the initial respiration level. All these responses are typical of bovine epididymal spermatozoa.
\end{abstract}

\section{INTRODUGTION}

A problem of substantial proportions in determining the kind of substrates utilized by mammalian spermatozoa and the biochemical metabolic pathways followed in the utilization of such substrates has been that of routinely obtaining cells free of endogenous carbohydrate or of other substrate absorbed from that part of the seminal plasma contributed at ejaculation by the accessory glands. In the bull the secretion of the seminal vesicles, making up as much as $75 \%$ of the volume of the normal ejaculate, is high in fructose which is rapidly absorbed by the spermatozoa upon contact at ejaculation. This carbohydrate uptake occurs under either aerobic or anaerobic conditions. The rate of the uptake in freshly ejaculated cells is dependent upon temperature, $\mathrm{pH}$ and possibly a number of undiscovered factors (Cragle \& Salisbury, 1959).

Under some conditions the uptake of carbohydrate may proceed at rates greater than the true rate of utilization for replenishment of adenosine triphosphate supply. Certain ions (Cragle \& Salisbury, 1959), especially the partial pressure of carbon dioxide $\left(p \mathrm{CO}_{2}\right)$ (Salisbury, VanDemark, Lodge \& Cragle, 1960), will depress it. Investigators have attempted to reduce the influence of this rapid uptake of carbohydrate on subsequent metabolic activity by washing the cells free of seminal plasma soon after collection. These washed cells have then either been used immediately (Bishop \& Salisbury, 1955) for the metabolic studies, or have been permitted to respire for a short period of time to 
oxidize any absorbed seminal nutrient before being subjected to the substrate under test (Hartree \& Mann, 1958). In spite of this washing, however, the exposure of the cells to the fructose-containing plasma after ejaculation has introduced variables into the metabolic studies which cannot be readily eliminated by these means (unpublished results).

Progress in eliminating this variable in metabolic studies was found to be impossible until after the discovery of the inhibition of the metabolic rate and of hexose uptake by increasing the $p \mathrm{CO}_{2}$ and the discovery of the depressive effect of high K-ion concentration on the motility of sperm cells (Cragle \& Salisbury, 1959; Salisbury et al., 1960). It is the purpose of this report to present a method for collection of spermatozoa inhibited on ejaculation in motility and metabolic function so that the normal carbohydrate uptake can be controlled. Such cells have many characteristics in common with epididymal spermatozoa. They, like bovine epididymal spermatozoa, have a low endogenous respiration and high aerobic glycolysis as compared to washed ejaculated spermatozoa (Lardy, Hansen \& Phillips, 1945; Salisbury, Graves, Nakabayashi \& Cragle, 1963). Because of this similarity they have been designated epididymal-like cells (ELC) (Graves \& Salisbury, 1959). They present opportunities for determining with increased precision and without confounding with seminal carbohydrate participation the part played by various substrates in the metabolism and economy of the spermatozoon.

\section{MATERIALS AND METHODS}

The technique finally chosen was the direct collection of semen into an artificial vagina to which was attached a $100-\mathrm{ml}$ volumetric flask containing an inhibitory diluent. After preliminary investigations (Graves, 1959) setting the parameters of the collection technique, including the composition of and the volume of the inhibitory diluent to be used so as to obtain non-motile spermatozoa, the metabolic activity of such cells was measured. For the comparative purposes of this report, collection was made into an artificial vagina containing in the collection flask $100 \mathrm{ml}$ of a solution of one of the following isosmotic diluents:

(A) $1.4926 \mathrm{~g} \mathrm{NaHCO}_{3}, 0.9231 \mathrm{~g} \mathrm{KHCO}_{3}$ and $1.890 \mathrm{~g} \mathrm{C}_{6} \mathrm{H}_{8} \mathrm{O}_{7} . \mathrm{H}_{2} \mathrm{O}$.

(B) $0.8146 \mathrm{~g} \mathrm{NaHCO}_{3}, 1.7301 \mathrm{~g} \mathrm{KHCO}_{3}$ and $1.890 \mathrm{~g} \mathrm{C}_{6} \mathrm{H}_{8} \mathrm{O}_{7} . \mathrm{H}_{2} \mathrm{O}$.

(C) $0.9 \% \mathrm{NaCl}$.

Water $(100 \mathrm{ml})$ was added to the dry components of the inhibitory mixtures (A and B) just prior to collection, evolving carbon dioxide and saturating the solution. The air phase above the liquid was replaced by gassing with $100 \%$ carbon dioxide. After collection, mineral oil was added over the diluted semen. Air was the gas phase above the saline solution which served as the control. Motility of the cells was estimated by microscopic examination of the diluted semen drawn into a capillary tube.

For the metabolic studies the cells were removed from the collection diluents by centrifugation and the supernatant, containing the diluted seminal plasma, was removed. The cells were resuspended and washed in fresh supplies of the 
collecting diluent, again centrifuged, and finally suspended to a concentration of 100 to $200 \times 10^{6}$ cells $/ \mathrm{ml}$ in $0.9 \% \mathrm{NaCl}$. Ejaculates were also collected in Diluent B and stored in this collecting diluent for $24 \mathrm{hr}$ at $5^{\circ} \mathrm{C}$. After the 24-hr storage period, the spermatozoa were removed from the inhibitory diluent by the technique described above. All metabolic measurements were made at $37^{\circ} \mathrm{C}$ for $4 \mathrm{hr}$ in a Warburg respirometer, using $17-\mathrm{ml}$ single sidearm flasks, with air as the gas phase. Potassium hydroxide was placed in the centre well of the flasks to absorb the carbon dioxide. The oxygen uptake, the fructose utilization in the presence of this substrate and the lactic acid accumulation, as well as the percentage and rate of motility after the incubation period were used as indicators of the similarity of these ELC to epididymal spermatozoa.

\section{RESULTS}

The cells collected in Diluents A and $\mathrm{C}$ were motile when examined immediately after collection. The motility in saline solution was maximal, while that in Diluent A ceased within approximately $2 \mathrm{hr}$ after collection. This latter diluent contained $360 \mathrm{mg} \mathrm{K}$ and $407 \mathrm{mg} \mathrm{Na} / 100 \mathrm{ml}$. The $\mathrm{K}$-ion level of this diluent was approximately the same as that found in the testes, whereas the potassium : sodium relationship was less than has been found in that organ (Salisbury \& Cragle, 1956) but similar to that found in seminal vesicular fluid. The cells collected directly into Diluent B were immotile on examination immediately after collection. They remained immotile in the collecting diluent, as long as air was excluded, for several hours at room temperature and for at least 8 days at $5^{\circ} \mathrm{C}$ until washed free of the diluent. This diluent contained $675 \mathrm{mg} \mathrm{K}$ and $220 \mathrm{mg} \mathrm{Na} / 100 \mathrm{ml}$, giving a potassium : sodium level of approximately $3: 1$ and similar to that found in the testes (Salisbury \& Cragle, 1956).

If the carbon dioxide in the A and B diluents was replaced by air (which occurred after placing a small amount of the solution on an open slide held at $37^{\circ} \mathrm{C}$ ), the cells soon became motile. This initiation of motility of the cells in Diluent $B$ could be further stimulated by dilution of the sample with physiological saline solution, indicating that not only was replacement of the carbon dioxide necessary before optimum motility was initiated but that the dilution of $\mathrm{K}$-ion by sodium was also involved. When combined with a $p \mathrm{CO}_{2}$ of $100 \%$ atmosphere, the high level of $\mathrm{K}$-ion in the diluent was more effective in inhibiting the motility of the cells than it was in reducing anaerobic substrate uptake (Cragle \& Salisbury, 1959; Salisbury et al., 1960).

The metabolic response of the cells is shown in Table l. The 4-hr endogenous oxygen uptake values are similar for all three diluents and are typical of the values found in this laboratory (Salisbury $e t$ al., 1963) and by others (Lardy $e t$ al., 1945) for epididymal bovine spermatozoa. These values are less than half the endogenous respiration found for washed ejaculated cells subjected to the fructose substrate in the semen from ejaculation to washing (Salisbury \& Nakabayashi, 1957; Nakabayashi \& Salisbury, 1959). Fructose added to the incubation medium increased the respiratory rate to levels characteristic of the initial endogenous respiration of washed ejaculated cells (Salisbury et al., 1963). 


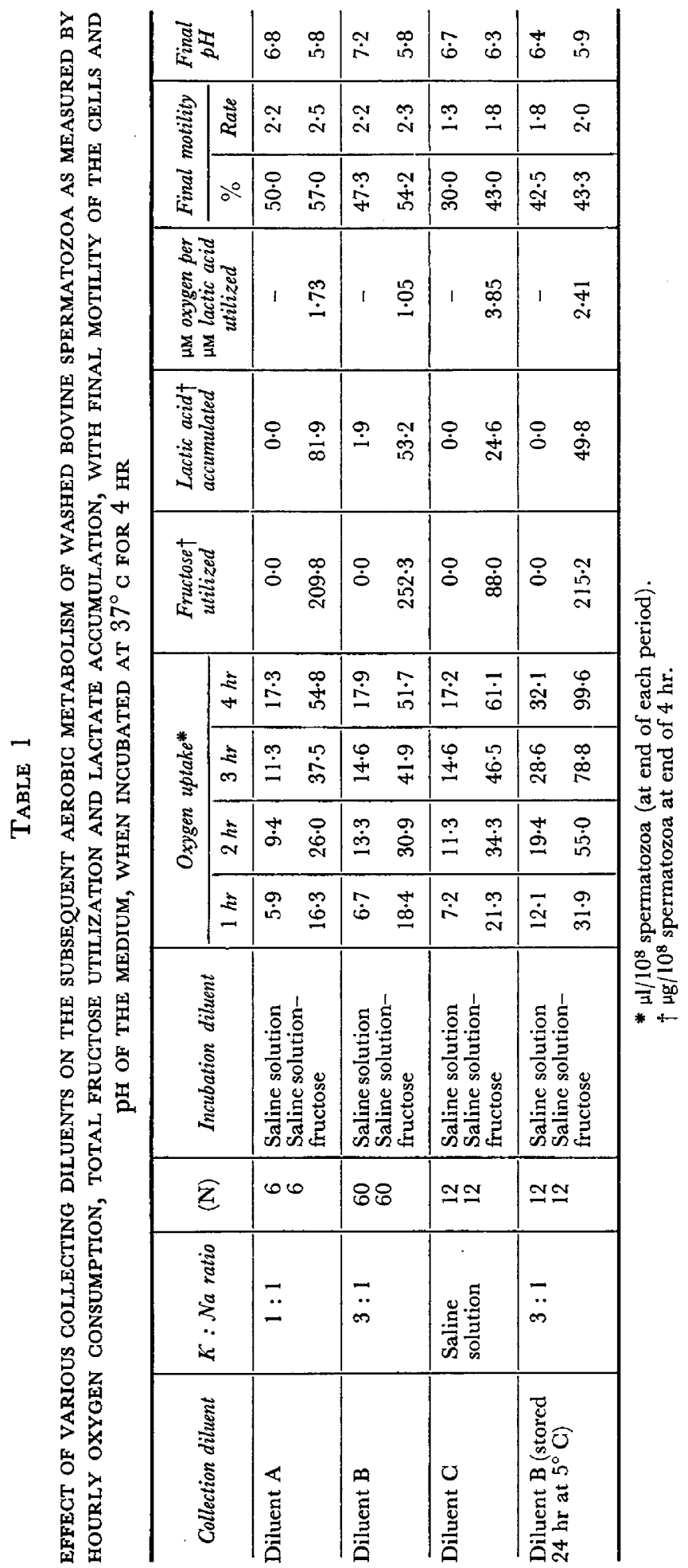


Since the primary difference in initial metabolic response between the ELC as described here and washed ejaculated cells appeared to be an exposure of the latter cells to high levels of fructose in the seminal plasma for short periods of time after collection, cells collected in inhibitory Diluent B were placed, after washing, in saline solution containing $500 \mathrm{mg} / 100 \mathrm{ml}$ fructose, a level approximating the mean level of fructose in semen, for $30 \mathrm{~min}$ at room temperature. These pre-conditioned cells were then washed free of exogenous substrate and resuspended in saline solution; oxygen uptake was measured at $37^{\circ} \mathrm{C}$. The results are reported in Text-fig. 1. A portion of the same ejaculate, but not conditioned in the fructose solution, served as a control. The endogenous oxygen consumption of the ELC conditioned in fructose, however, was nearly twice that of the controls, and typical of washed cell metabolism. As is evident from Textfig. 1, conditioning had no effect on oxygen uptake in the presence of fructose.

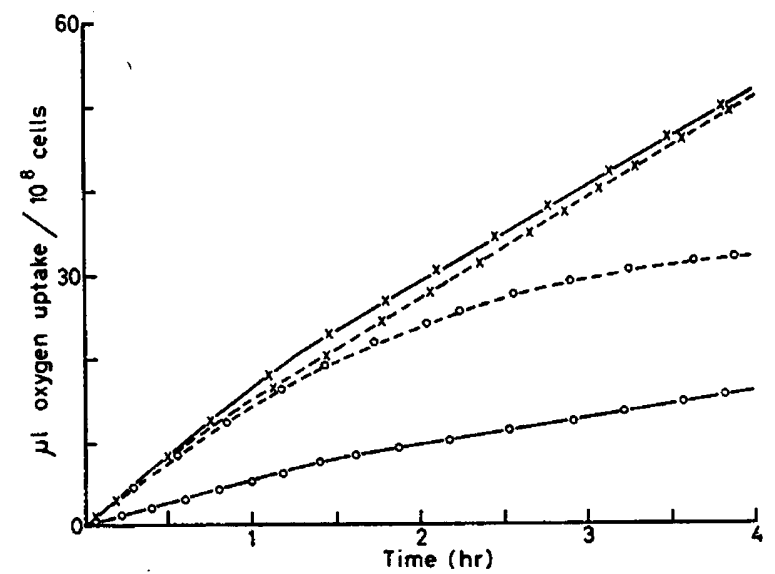

TEXT-FIG. 1. Effect of conditioning ELC in $0.027 \mathrm{M}$-fructose for $30 \mathrm{~min}$ at room temperature on their subsequent respiration in saline solution and in $0.027 \mathrm{M}$-fructose diluents during a 4-hr incubation period at $37^{\circ} \mathrm{C}$.

- Epididymal-like cells

... Epididymal-like cells after conditioning $30 \mathrm{~min}$ in fructose at $27^{\circ} \mathrm{C}$. Saline solution.

Saline solution-fructose.

Finally, three ejaculates were collected in the inhibitory Diluent B and samples were stored for $24 \mathrm{hr}$ at $5^{\circ} \mathrm{C}$. During this period of storage the cells were immotile. Upon subsequent removal and washing there resulted from four replicates on each ejaculate, as is shown in Table 1 , a highly significant increase both in endogenous respiration of the cells and in that of those receiving added fructose as a substrate, as compared to the response before the storage. This increase may be due partly to the slow absorption of substrate during the 24-hr storage, though chemical analysis of the suspension before and after the 24-hr period showed no measurable change in the fructose level. The respiration in the presence of added fructose, however, was so much greater for the stored samples than for those measured soon after collection, or for those conditioned in fructose, as to suggest, as reported by Lardy et al. (1945) that a regulator to respiration was released from the cells during the 24 -hr storage at $5^{\circ} \mathrm{C}$. Later 
studies, however, did not give this highly consistent stimulation to respiration resulting from storage, more variable results being obtained.

Spermatozoa collected into Diluent B and subsequently washed and resuspended in the Illini Variable Temperature Diluent (VanDemark \& Sharma, 1957) were shown to be fertile after 24-hr storage. The number of females inseminated was insufficient to ascribe a quantitative figure to the fertility level.

\section{DISCUSSION}

In addition to fructose, there are other substrates provided by bull semen which may be utilized by the spermatozoa to produce mechanical energy. Such substrates, too, would gain access to the energy-transforming metabolic channels in spermatozoa in the period before washing when normally collected spermatozoa are suspended in the seminal plasma. For example, normally-collected bull semen contains appreciable quantities of lactic acid (VanDemark, Mercier \& Salisbury, 1945). It also contains, soon after collection, a detectable amount of acetic acid (Flipse \& Potter, 1955; Ramsey, Lodge, Graves \& Salisbury, 1963). Recent experiments (Graves \& Salisbury, 1960) with the ELC demonstrated the rapid oxidation of acetate.

However, we have confined the substrate offered the cells in the present studies to fructose as it is the principle substrate supplied in bull semen for energy metabolism. Its utilization by the ELC in a manner reminiscent of the washed ejaculated cells would support our contention that a primary difference between epididymal and ejaculated cells is the immediate absorption of substrate by the spermatozoa upon ejaculation and mixing with the substraterich products of the male accessory sex glands. Evidence from the metabolism of spermatozoa collected directly into the three different diluents, after washing and resuspension in physiological saline solution, shows conclusively that the primary cause of the initial substrate deprivation is the dilution of the substrates provided in the semen, for the endogenous respiration of the cells collected directly into physiological saline solution was no greater than that of those collected into the two inhibitory ones. The dilution rate involved by ejaculation directly into the three diluents was about one part of semen to ten to twenty-five parts of the diluent.

The endogenous substrate for spermatozoan respiration has not been identified precisely, though for ram spermatozoa it has been shown to be plasmalogen fatty acids (Hartree \& Mann, 1961). However, the endogenous respiration of ELC in our study persisted at a relatively low level, during the 4-hr period, and the final motility estimate for the cells was nearly as high as when fructose was added. This fact suggests that endogenous oxidation provided adequate energy for motility, but no studies were conducted to determine whether the endogenous substrate was of spermatozoan reserves or of other vital structure.

In the presence of added fructose the mean oxygen consumption by the cells was adequate to account for the mean net disappearance of fructose to carbon dioxide and water only in the case of the spermatozoa collected into $0.9 \%$ $\mathrm{NaCl}$. If it is assumed that all of the fructose which disappeared was converted to lactate, then the difference between it and the lactate which accumulated 
represents the amount of lactate which was oxidized. Thus, $3 \mu \mathrm{m}$ of oxygen would be required for complete oxidation of each $\mu \mathrm{m}$ of lactate. The fact that the cells collected in the inhibitory Diluents, A or B, used insufficient oxygen, on subsequent resuspension in saline-fructose solution, completely to oxidize the lactic acid, suggests that an unknown intermediate was accumulated. Current evidence indicates that this is neither acetate nor pyruvate. Something common to both the inhibitory diluents appears to be responsible for this difference which is primarily an increased uptake of fructose as compared to that which occurs when the cells are collected directly into saline solution. A carry-over effect of the high carbon dioxide level, present in collection Diluents A and B, may be the responsible factor, since carbon dioxide is known to pass readily across cell membranes and might enhance subsequent fructose uptake by acting on the cell permeability, the effect persisting into the saline suspension medium. On the other hand, the cause might be a carry-over influence of bicarbonate and citrate, also common to Diluents A and B. The rapid uptake of fructose is characteristic of normal epididymal spermatozoa (Lardy et al., 1945; Salisbury et al., 1963).

Another characteristic of ELC, reminiscent of epididymal spermatozoa, is illustrated by the increase in metabolic rate after storage for $24 \mathrm{hr}$ at $5^{\circ} \mathrm{C}$. This characteristic, tested only in Diluent $B$, suggests that a substance inhibitory to energy exchange is released from the cell during that storage. This observation is consistent with that reported by Lardy et al. (1945) as typical of bovine epididymal spermatozoa, and considered by Rödel (1955) to be due to sulphide release by a cysteine desulphydrase isolated from the bovine epididymis. Whether or not this phenomenon would have occurred in the other two collecting diluents is not known.

Diluent A was the first inhibitory collection diluent developed by us. After testing a number of other mixtures (Graves, 1959) Diluent B was developed containing the potassium : sodium ratio of approximately $3: 1$ which is similar to that found in the fluids of the excurrent ducts of the bovine testes (Salisbury \& Cragle, 1956). A high level of potassium in the epididymis appears to be an important factor in the quiescence of bull spermatozoa in the lumen of that organ. Potassium probably functions as found by Ringer (1886) in frog sartorii, and possibly it inhibits the activity of the enzyme, adenosine triphosphatase, as found in perch sperm flagella by Tibbs (1959). The complementary effect of the carbon dioxide tension and of K-ion on immediate inhibition of spermatozoan motility at ejaculation may be similar to the situation for frog nerves described by Fenn \& Gerschman (1950), who found that $p \mathrm{CO}_{2}$ of $20 \%$ in oxygen influenced cellular K-retention depending upon the composition of the suspending fluid.

A major source of much of the statistical variation in studies of bovine spermatozoa metabolism is associated with the particular ejaculate obtained. This ejaculate-to-ejaculate variation is reduced by the technique of collection into an inhibitory diluent. However, because each whole ejaculate can be collected only into a single diluent the variation associated with ejaculates is confounded with the variation contributed by the three different collection diluents employed. Yet, the motility differences noted immediately after collec- 
tion, the smaller amount of fructose used by the cells collected in saline solution, and the ratio of oxygen to substrate utilized appear to be real differences due to the nature of the collecting diluents used.

The authors feel that the epididymal-like substrate-free sperm cells collected in Diluent B should be of considerable value for studying the types of substrates utilized by spermatozoa. Also they should prove valuable for the solution of problems concerning the initiation of motility at ejaculation, membrane permeability, and other problems where the substrate absorbed by the cells from the seminal fluid may prejudice the experiments. This method of collection, adapted to other animals, may eliminate some of the species differences which, although due to the differences in the make-up of the seminal plasma, are evident in metabolic studies when whole semen or even washed spermatozoa are used (Salisbury \& Lodge, 1962).

\section{ACKNOWLEDGMENTS}

The authors acknowledge with appreciation the help of their colleague, J. R. Lodge, in the preparation of this manuscript and the financial assistance of the Curtiss Improved Stud Service, Cary, Illinois which enabled one of us (C. N. G.) to pursue graduate studies at the University of Illinois.

\section{REFERENCES}

Bishop, M. W. H. \& SAissbury, G. W. (1955) Effect of dilution with saline and phosphate solutions on oxygen uptake of bull semen. Amer. F. Physiol. 181, 114.

Cragle, R. G. \& Salisbury, G. W. (1959) Factors influencing metabolic activity of bull spermatozoa. IV. pH, osmotic pressure and cations, sodium, potassium and calcium. F. Dairy Sci. 42, 1304.

Fenn, W. O. \& Gerschman, R. (1950) The loss of potassium from frog nerves in anoxia and other conditions. F. gen. Physiol. 33, 195.

Flipse, R. J. \& Potter, F. E. (1955) Presence of volatile fatty acids in bovine semen. Proc. Soc. exp. Biol., N.Y. 89, 432.

Graves, C. N. (1959) The production of epididymal-like spermatozoa. M.S. thesis, University of Illinois.

Graves, C. N. \& SAlisbury, G. W. (1959) The production of epididymal-like ejaculated bovine spermatozoa. 7. Dairy Sci. 42, 932.

Graves, G. N. \& Salrsbury, G. W. (1960) Effect of various substrates and inhibitors on the respiration of bovine epididymal-like spermatozoa. F. Dairy Sci. 43, 881.

Hartree, E. F. \& Mann, T. (1958) Plasmalogen in ram semen, and its role in sperm metabolism. Biochem. F. 71, 423.

Hartree, E. F. \& Mann, T. (1961) Phospholipids in ram semen: Metabolism of plasmalogen and fatty acids. Biochem. F. 80, 464.

Lardy, H. A., Hansen, R. G. \& Phillips, P. H. (1945) The metabolism of bovine epididymal spermatozoa. Arch. Biochem. 6, 41.

Nakabayashi, N. T. \& Salisbury, G. W. (1959) Factors influencing the metabolic activity of bovine spermatozoa. V. Season. 7. Dairy Sci. 42, 1806.

Ramsey, H. A., Lodge, J. R., Graves, G. N. \& Salisbury, G. W. (1963) Organic acids in fresh bovine semen. F. Dairy Sci. (In press).

RINGER, S. (1886) Further experiments regarding the influence of small quantities of lime, potassium and other salts on muscular tissue. F. Physiol. 7, 291.

Rödel, L. (1955) Beitrag zur Mechanismus der Spermienreifung in Nebenhoden. Fortpfl. Zuchthyg. Haustierbesamung, 5, 49.

SAlisbury, G. W. \& CRAGLe, R. G. (1956) Freezing point depressions and mineral levels of fluids of the ruminant male reproductive tract. Proc. IIIrd int. Congr. Anim. Reprod., Cambridge, p. 25.

Salisbury, G. W. \& Lodge, J. R. (1962) Metabolism of spermatozoa. Advances in Enzymology, vol. 24, p. 35. Ed. F. F. Nord. Interscience, New York.

Salisbury, G. W. \& Nakabayashi, N. T. (1957) Effect of phosphate and chloride ions on aerobic metabolism of bovine spermatozoa. F. exp. Biol. 34, 52. 
Salisbury, G. W., Graves, G. N., Nakabayashi, N. T. \& Cragle, R. G. (1963) Observations on the aerobic metabolism of bull and goat epididymal spermatozoa. F. Reprod. Fertil. 6, 341.

Salisbury, G. W., VanDemark, N. L., Lodge, J. R. \& Gragle, R. G. (1960) Inhibition of spermatozaan metabolism by $p \mathrm{CO}_{2}, \mathrm{pH}, \mathrm{K}$ ion and anti-bacterial compounds. Amer. $\mathcal{J}$. Physiol. 198, 659.

TrBBs, J. (1959) The adenosine triphosphatase activity of perch sperm flagella. Biochim. biophys. Acta, $33,220$.

VanDemark, N. L. \& Sharma, U. D. (1957) Preliminary fertility results from the preservation of bovine semen at room temperature. 7. Dairy Sci. $40,438$.

VanDemark, N. L., Meraier, E. \& Salisbury, G. W. (1945) The methylene-blue reduction test and its relation to other measures of quality in bull semen. $\mathcal{F}$. Dairy Sci. 28, 121. 